FACTA UNIVERSITATIS

Series: Philosophy, Sociology, Psychology and History Vol. 17, Nº 1, 2018, pp. 37 - 54

https://doi.org/10.22190/FUPSPH1801037S

Review Paper

\title{
ONLINE MEDIA AS CONFLICT GENERATORS
}

UDC 070:004.738.5]:327(497.11:497.13)

\section{Ivana Stamenković, Miljana Nikolić, Dušan Aleksić}

University of Niš, Faculty of Philosophy, Deparment of Communicology and Journalism, Serbia

\begin{abstract}
The media have always had great influence on the construction of attitudes and opinions of the public, thus it comes as no surprise that they constantly adjust to contemporary tides and the ways in which the public obtains information. Thanks to the popularity and possibilities offered by the Internet, the media were forced to converge towards online forms of reporting. Besides this, the Internet enabled the removal of state limits when it comes to informing, so the public can learn more easily about events from all over the world. In this way, mass-media communication gets new outlines while directing social tides on the global level. Although such a trend can be useful, it can also carry certain dangers. Therefore, the new media can become a platform for international conflicts and lead to possible interruption of good relations among states. Considering the fact that relations between Serbia and Croatia are characterised by a now concluded war, this paper examines the way in which the Serbian and the Croatian online media report on the relationship between the two states from the perspective of political relations, media presentations of each other, as well as how large the role of the modern media is in provoking new conflicts. Using a quantitative-qualitative analysis of the content, both the Serbian and the Croatian versions of the portal " 24 hours" were analysed within the period from April 1 to April 30, 2017.
\end{abstract}

Key words: the Internet, conflicts, Serbia, Croatia, new media, reporting.

\section{INTRODUCTION}

Although the war in former Yugoslavia officially ended more than 20 years ago, many questions have remained open, especially concerning the relations between Serbia and Croatia. Even though political leaders declaratively propagate peace and stability within the region, the messages whose rhetoric reminds us of the 1990s can occur from time to time. At that time, the same as today, the media had the key role in transmitting

Received July 10, 2017 / Accepted May 22, 2018

Corresponding author: Dušan Aleksić

University of Niš, Faculty of Philosophy, Cirila i Metodija 2, 18000 Niš, Serbia

E-mail: dusan.aleksic@filfak.ni.ac.rs 
those messages. The key difference is that today we live in the age of media pluralism, information sources are far more numerous, and technological development has contributed to the fact that the media have become more interactive. The development of the Internet has provided a far greater choice of content. The platform set in such a way gives an opportunity to bridge the gap created several decades ago. However, the question is whether this potential is used, that is, whether the contemporary media are the generators of hatred, as was the case during the war years. The same as technology, the media also evolve and adapt to contemporary trends (presence on social networks, provision of interactive services, and the like). Their progress regarding form is indisputable, but the focus of this paper is the question of content, that is, in what way Serbia is presented in the Croatian media and vice versa.

Even after the end of the war, topics such as religion, social and state ideologies, and sport events provoked strong reactions on both sides. When it comes to the role of the media, it should be noted that today the number of different media is far greater than it was 20 years ago ${ }^{1}$, that the market is much more competitive, which questions the ways which media companies use to attract as many users as they can, especially from the perspective of journalism ethics. As we have already mentioned, the relation between Serbia and Croatia has always been a burning issue, which leaves room for the media to reactivate the conflict points in this relation, knowing that it would always attract an audience, a large number of comments on web portals, and a higher reading percentage. On the other hand, this subject can also be misused for political purposes in order to move the attention from more important subjects. In this way, the conflict is not resolved but only transferred to a new, virtual environment, and old rivalries are revived, in which the Other can always be marked as the guilty party. If this is accompanied with the fact that the flow of information on the Internet is free, new opportunities are opened for the dissemination of false information which is accepted by the users as media content without additional checking, which can only make these relations more complicated. In that way, young people, as active users of social networks, become the consumers of such content, so they start to construe images and inherit negative discourse on the basis of these media images, although they were not even born during the conflict (Vujović \& Obradović 2017).

That is why one of the aims of this paper is to examine the role of contemporary media in provoking conflict, as well as the media representation of the "opposing" side.

\footnotetext{
${ }^{1}$ According to Saša Mirković, the State secretary at the Ministry of Culture and Information, the number of registered public media at the Serbian Business Registers Agency is 1,379, out of which 107 are television media and more than 350 are radio stations. In detail: http://www.blic.rs/vesti/drustvo/u-srbiji-registrovano1379-medija/7pchmcb.

The number of public media is continuously on the rise, and as NUNS claims, a significant contribution to increasing this number is given by the illegal media which are present even today. It is more important to take into account non-transparency of the owner structure when it comes to means of informing the public, being that the media consolidation collides with the option of the freedom of opinion and expression, that is, with public interest and a free, critical public opinion. In detail: http://www.nuns.rs/reforma-javnog-informisanja/strategija.html.
} 


\section{THE RECONSTRUCTION OF NATIONAL IDENTITIES IN TIMES OF CRISIS AND CONFLICT}

During the last decades of the twentieth century in the Balkans, the issues of the nation ${ }^{2}$, national identity ${ }^{3}$ and borders have become a point of contention among the countries from this region. Đorđe Stojanović and Milena Pešić $(2016,37)$ point out that the basic approaches to national identity in science are primordialist or essentialist, and instrumentalist and constructivist. According to the first approach, "the feeling of community is based on the idea of mutual origin and historical experience of the community, as well as on the shared myths, tradition and culture", while the second approach shows that "the national communities are created out of interest and they are artificially maintained as long as there are pragmatic reasons for that" (Stojanović \& Pešić 2016, 37-38). Branislav Stevanović (2013, 244) explains that the "ethnic and religious 'revival' in the Balkan region in the last decade of the $20^{\text {th }}$ century, brought about the predominance of the concept of reaffirmation of the national cultural identity in cultural politics". One of the preconditions for the formation of the states was the existence of collective identities ${ }^{4}$ which found their support within the national borders.

Slobodan Miladinović $(2009,13)$ emphasises that the "collective identity in a fragmented society cannot be any different than fragmented and partialized, broken down into a large number of subidentities marked by national, religious, territorial and social signs". Each identity is constructed in relation to the Other, so the very differences among Balkan countries represented, as they represent today, important constituents of national identities. There are a lot of elements of separation; however, as the main ones, Milan Tripković $(2005,102)$ states those which come from different religions or differences in religions, from cultural-historical differences of life in the previous national formations and from different or differently understood and experienced external supports and helpers. Discussing the question of identity and analysing the term itself, Branislav Stevanović $(2013,259)$ concludes that "there are no 'self-made identities', but only those which are constituted in 'relation to others' and which are the result of that relation". This kind of attitude implies the importance of intercultural communication, which has to be based on the respect of diversity. It implies the establishment of dialogues and the exchange of cultural contents and contributes to the enrichment of cultures which are in contact with one another. However, peoples in the Balkans needed the Other which would be considered an enemy, and in relation to which they would emphasise their uniqueness. The concept of "the narcissism of small differences", which was discussed by Sigmund Freud, can explain the cause of the conflict among Balkan countries. According to this theorist, animosity is directed towards those who are most similar to us, because we see ourselves in them, and that jeopardizes our uniqueness. Therefore, in order to create our own

\footnotetext{
2 Đorđe Stojanović and Milena Pešić $(2016,40)$ emphasise the opinion of Benedict Anderson who states that "being a nation' is not related to large cultural systems which have created a certain referential framework, and those are the religious community and the dynastic kingdom which preceded it, and out of and against which they developed".

${ }^{3}$ Đorđe Stojanović and Milena Pešić $(2016,31)$ explain that "the nation and the national identity cannot be reduced to an ideology or a form of politics without necessary cuts, because every complete scientific insight, even only into these two dimensions of the problem, requires their wider observation and interpretation in the anthropological and cultural light, and always in the socio-cultural context".

${ }^{4}$ The term collective identity should imply a complex system of values, beliefs, symbols, patterns of behaviour, etc., which develops within the processes of personal and long-term crystallisation of collective experiences of the members of one community" (Stevanović 2013, 263).
} 
identity, it is necessary for us to find and emphasise differences (Stojković 2002, 86). A very common opinion of the Other is based on prejudices and stereotypical representations, on the basis of which a distorted image is created in people's consciousness. They can produce many negative feelings and cause aggressive behaviours with very dangerous consequences. Dušan Kecmanović $(2002$, 50) points out that people justify ethnic prejudices by a projection mechanism, which implies that hatred towards other people is only a way to defend oneself from the hatred they already receive from them. Considering the fact that this makes them feel threatened, they find ways to limit, disrespect and destroy the members of other ethnical communities. At the same time, they represent themselves as the victims of the conflict. David Bruce MacDonald $(2002,39)$ explains that during the period of disintegration of Yugoslavia this very pretending to be the victim was the central part of Serbian and Croatian propaganda, thus legitimizing the violence which was necessary in order to create expanded homelands.

In times of crisis, as there were in the Balkans during the last decades of the $20^{\text {th }}$ century, very often there occurred a loss of a personal identity and then, a man turns to a group, seeking direction and safety within it. Slobodan Miladinović $(2009,17)$ states that, in those times, it is "necessary to rationalize the crisis, and the easiest way to perform rationalization is when easily-acceptable culprits for the current social problems can be identified. The simplest way is to put the blame on a member of the group with which there is some form of historical rivalry, and those are, most often, other ethnic or religious groups". The group constructs its identity in relation to the assumptions it has of the Other. An individual accepts that identity as his/her own, while also adopting those assumptions which enable him/her to direct their behaviour. There is mistrust towards someone who is different, which, in fact, originates from not knowing. If we add here the relations between the Balkan peoples which have been full of conflict, it becomes clear why nationalism was, and still is, widespread in this region. According to Milan Tripković, during the 1990s, there was a "politisation of ethnicity":

"Contrary to the general trend of certain relativisation, partial blend-in or softening and fading away of the national borders and national sovereignty, through the integration of the national states into wider and more organised international frameworks, the ideal of 'the national state' experienced its absolutisation here, primarily through a clear distinction from the immediate surroundings of the 'others' who were experienced as centuries-old and undisputable enemies by birth" (Tripković 2005, 104).

Very often, an individual accepts nationalistic attitudes because he/she fears that if he/she does not do that, he/she will be unaccepted and ostracized from the group. It is in this very fact that Slobodan Miladinović $(2009,15)$ sees one of the reasons why people accept nationalistic attitudes, including also "cultural legacy" and ethnic stereotypes which are uncritically accepted through socialization, but also the frustration due to unsatisfied needs. Frustrations cause aggressiveness, expressed by an individual exactly towards individuals from other groups. Dušan Kecmanović $(2002,47)$ also agrees with this, and explains that when the level of aggressiveness reaches a certain point, there is no more need for a stimulus which is usually connected with aggressive behaviour: "You can lose your life simply because someone thinks that you have looked at him askance". Considering the fact that an individual automatically accepts attitudes, values and ideas promoted by the group, he/she does not develop the need to question, so he/she is more 
susceptible to manipulation. In this case, there is a possibility for him/her to be used for achieving the aims of other individuals and interest groups.

Contemporary information-communication technologies provide access to a great deal of information, which enables an individual to construct his/her identity by himself/herself. On the one hand, the expansion of the new media gives him/her an opportunity to choose what he/she reads, but, on the other hand, the lack of control of Internet content carries with it the danger of manipulation. Plenty of untruthful data which come from unreliable sources find their place in the online world, and the modern man/woman becomes the victim of such content very easily. If he/she creates his/her opinion and attitude, and therefore his/her identity, according to these, he/she can create prejudices and stereotypical representations about others, which are suitable for the expansion of nationalism. The collective identity of the Balkan peoples gained the outlines of a nationalistic one a long time ago and it has become a threat to democratic progress and multiculturalism. Branislav Stevanović offers the solution to this problem:

"Contrary to the primordialist concept which defines national culture as the expression of the autonomous spirit of the national community, the only way for the national cultures in the Balkans to make peace and respect each other is that the borders between them are not treated as the lines of perpetual discord. The space of contemporary culture is most surely not a simple expression of the unique 'national spirit' on a certain territory, but also the space of communication, the field in which there is an exchange of not only the finished cultural goods, but also those places where they are created" (Stevanović 2013, 248).

\section{THE MEDiA AS the CREATORS OF A REPRESENTATION OF THE OTHER}

Fabrication of meaning represents one of the main activities of the media. The formation of group identities is based on the images created by the producers of the media content. The way in which the world will recognize us and the way in which we will perceive others depend on the meaning which the media relate to certain groups. The versions of the world which are favoured by those who hold the power in society are channelled through the media and in that way, through the use of certain verbal and visual entries, reach the media public who often accepts them without questioning. The representation of reality is possible from different perspectives, but a certain perspective is given preference because it fits into the interests of the ruling elite. ${ }^{5}$ This elite organizes all modalities of reality representation: who speaks of it, how it is spoken of and who has the power to represent it in a certain way (Đorđević 2009, 17). The media strategies which are used in the process of representing one's identity, one's own group and a group of strangers, that is, other groups, usually lead to the symbolic superiorisation of the firstmentioned group and inferiorisation of all others which are distinguished by a multitude of criteria - language, religion, ethnicity, etc. Starting from the 1960s, various social groups

\footnotetext{
${ }^{5}$ The agenda setting theory explains how certain topics, after a careful selection, obtain prominent places within the media space, be it printed or digital media. Considering the fact that certain topics, individuals, events and social events are preferred in the media discourse, such a place is also occupied in the perceptions of citizens, the users of media information. The foundations of this theory were set in 1922 by Walter Lippman, and it was further developed, shaped and complemented by McCombs and Shaw.
} 
which have formed on the basis of innate factors, as well as on acquired beliefs, have started to fight against marginalization in the society which only values the mainstream cultural pattern. ${ }^{6}$ Thinking about the significance of media representation, Danka NinkovićSlavnić $(2011,16)$ notes that this process is inextricably linked with reality, as well as that this relation gives sense to social phenomena and groups. The author writes: "Representation is a process of the production of meaning which operates through two kinds of representation systems: the first one, which organizes the world into meaningful patterns and categories; and the second one, a system of signs used for sharing the same categories with other members of society. Through representation, the continuous complex world is organized by the fact that certain things, that is, in the case of humans, their traits are selected and categorized, marked and communicated.

The awareness of the media representation of identities of different groups becomes more and more clear and pronounced, and the struggle of these groups to become a part of the mosaic of media images, which reflects the stronghold points of their identity, as well as their needs, becomes fiercer and fiercer. In the process of constructing the meaning about others, the traditional media were also joined by the new media at the end of the $20^{\text {th }}$ century. The power of the new media is empowered by technological innovations and the creation of Web 2.0, which was the starting point of a new era in communication in which the user of the media content becomes the creator and the active participant of media communication. In this way, the struggle for the mastery and control of the symbolic field expands from the traditional media to the new media and communication means whose influence is now even greater, especially among the younger population. ${ }^{7}$ Although the democratic capacity of the Internet is widely discussed by theorists and researchers of public communication, it seems that technology by itself cannot awaken the public spirit of criticism and encourage the public to discuss socially relevant topics (Papacharissi 2002, 9). Within the virtual space of the Internet, there is a possibility for the revitalization of the public sphere, but such a venture depends on citizens who can initiate a meaningful debate, start and direct discussions on forums, portals and sites. Moreover, such communication is also more and more controlled, especially when it comes to online editions of traditional media. The rules of communication are well known, and each violation of some of those rules results in the exclusion of a user's comment, which is usually under the supervision of administrators and moderators of websites. Certain specificities of the Internet refer not only to the content, but also to the way in which it is organized and presented on online sites. Manovich $(2015,107)$ speaks of an overlap between the influences of software, the technical code with the contents created on the basis of conventional cultural codes. The field where they meet is labelled as 'interface' by the author. "The interface shapes the way in which the user of the computer understands the computer itself. It also determines the way in which a user thinks about any media item which is obtained through the computer. By taking away the original traits of various media, the interface imposes its own logic". The process of designing an interface for a portal is under the influence of the ideology of a

\footnotetext{
${ }^{6}$ Milan Mesić states that the number of social movements with the demand to recognize different identities has been increasing since the 1960s. The starters of these movements were, among others, national minorities, ethnic and racial groups, old and new immigrants, feminists, homosexuals and others (Mesić 2006).

${ }^{7}$ According to the Statistical Office of the Republic of Serbia, 59,9\% of households in Serbia owns a computer, while 55,8\% has an Internet connection. See in detail: http://www.nuns.rs/info/news/20168/u-srbiji-raste-brojkorisnika-interneta.html.
} 
hegemonic group which controls collective consciousness. The connection between the ideology and the new media and software was discussed by Galloway $(2012,55)$, whereby he discovered that ideological constructions hide behind the seemingly neutral software code. Thereby, he directly opposed the thesis on the liberal power of the new media, that is, the Internet.

Considering the fact that it is difficult to speak about the ideological neutrality of media discourse, be it in the case of the traditional or the new media, then it is advisable to critically analyse media content in order to reveal what kind of strategies are used in representing Others and Otherness. Among the most present media strategies which are used for representing minority groups, Ninković-Slavnić $(2011,19)$ includes: strategies of polarization, symbolic annihilations, blaming, media conformism and normalisation. Among them, the most used is polarization, which implies that the difference which exists between two groups is emphasised, and the similarities are minimized and removed. Ruth Wodak $(2011,49-50)$ analyses media texts and recognizes strategies which stress the positive traits of one's own group and the negative traits of other groups. Those are the following strategies: the strategy of nomination (referential), the predicative strategy, argumentative, the strategy of perspective from which the social problem is viewed and which discovers who constructs and defines world views, and the strategy of increasing positive and minimizing negative traits of one's own group. These strategies are used not only in the media representation of minorities, but also in the representations of other cultures, nations, and especially of neighbouring countries. The outcome of applying these strategies can also be to provoke conflicts or to expand the existing conflicts between two groups. The populist trend of reporting which dominates the media scene of Serbia resorts to these strategies, using provocative and sensational textual and visual content while representing others, and particularly those nations which are culturally, religiously and linguistically very close. The aim of such a media approach in reporting about the peoples in the region is to attract the public's attention in order to sell it an ideological story created on the basis of the imaginary interests of its own elite. In a public, media discourse, the opposing sides measure their strengths and struggle for supremacy in a symbolic sense, and the media receive a very important role during periods of crisis. At those times, one can recognise the capacities of the media in imposing a concrete attitude, preparation and possible mobilisation of citizens against the opposing group. In modern conflicts, the media can have a double role, they can initiate conflicts or suppress violence, that is, they can be agitators or peace-makers (Hannu-Pekka 2009, 15; Vulić \& Pavlović 2014). Whether the media will take the role of a violence instigator or they will inhibit violence and actively work on resolving the crisis depends on many factors, but the most important among them is the independency of a media company from the participants in the conflict (Puddephatt $2006,4) .{ }^{8}$ The mass propaganda induction of fear from real, but also imaginary enemies, the feeling of vulnerability, hopelessness, psychological disorientation and collapse of the value system were particularly noticed during the conflicts among the ex-Yugoslavian states during the 1990s. In such a disintegrated situation within society, importance is given

\footnotetext{
${ }^{8}$ During times of crisis, the ruling elite often misuses the media, and media tools become the most significant tools in the hands of those in power when there is an indication of conflicts with other countries. This was particularly noticeable in the region of former Yugoslavia in the 1990's when the media participated in the psychological preparation and mobilization of citizens for future conflicts and the war.
} 
to values, beliefs and interests which are based on the national heritage, whereby xenophobia, mistrust, and even contempt towards other ethnic groups and nations, are strategically strengthened. In the post-conflict period as well, the public discourse is marked by numerous linguistic manipulations and the use of stereotypes. "The images of war and the feeling of hostility from the past in the countries of ex-Yugoslavia are still present in the lives of their citizens, either in the form of memory or through media images" (StojanovićPrelević et al. 2014, 142). Believing they are the most operative rhetorical means, Đerić $(2008,263)$ thinks that stereotypes reflect the condition of society during the time of inquiry, being that they are closely related to the political, developmental and intellectual scene from which they originate. The modern discourse, as emphasised by the author, should be observed as "the collective mechanism of society control", but also as the medium through which the meanings in the language itself are broken and changed. The public language is important, as stated by Đerić $(2008,264)$, because it is assumed that it has influence on the formation of an individual, but also on wider social presentations. The access to the communication field and the option to control the symbolical capital, and indirectly the mind of recipients of media messages, show that a certain social group has the power to fabricate and impose their worldview: "The influences of the state and ideological systems are brought into dialectic dependency on constructing and deconstructing social problems, whereby the producers of ideological constructs, moral dilemmas, cultural patterns, symbols of good and evil, use the agenda theory to set the style and topics of political debates" (Jevtović \& Milašinović 2016, 533).

The changes in the way culturally close groups which are in the latent conflict or disagreement are spoken of and written about are closely related to the institutional changes of those societies. Analysing hate speech in the Croatian media, Gordana Vilović (2011, 68-69) concluded that there are three periods of this type of speech: the first one is the pristine form of hate speech which is characteristic for the period between 1990 and 1997; in the second period, the second period is marked by a concern to reduce the intensity of hate speech (1997-2000), while during the third period, starting from 2000 onwards, sanctioned hate speech in public discourse is replaced with the politically incorrect speech about national minorities, especially about the Serbian minority, as believed by Vilović. Although open hate speech has disappeared, the intolerant attitude towards the Other and 'the different' has been channeled by the political elite through the stereotypical images about multiple minorities (e.g. homosexuals).

\section{METHODOLOGICAL FRAMEWORK}

The subject of the research:

The traditional media have been joined by the new, interactive media which actively participate in the process of constructing the representation of the Other. This paper focuses on the analysis of the representation of the Other on the online news-portals in Serbia and Croatia. More precisely, the paper investigates the way in which Serbia is represented on the Croatian website "24sata.hr", and also the way Croatia is reported about on the Serbian portal "24online.info".

The main aim of the research:

To determine to what extent and in what manner Serbia is represented on the Croatian portal, and Croatia is represented on the Serbian portal. 
Specific aims:

To determine whether religious identity is used for the purpose of polarization.

To determine whether both sides make references to historical events in order to ignite conflicts.

To determine whether there are stereotypes and prejudices in reporting on the Croatian and Serbian portals.

To determine what kind of visual presentation of texts is on the portals.

To determine whether the texts are ideologically oriented towards the culture of peace or towards the provocation of conflicts.

Research method:

The paper uses a quantitative-qualitative analysis of the content of the Croatian portal "24sata.hr"9 and the Serbian website "24online.info"10.

\section{RESULTS AND DISCUSSION}

'24 sata' (24 hours) is the name of a daily newspaper published in both Serbia and Croatia. Although they share the same name, these newspapers do not have the same publisher, editorial staff, nor the same marketing approach. The Croatian edition has been published since March 2005 by an Austrian company called Styria Medien AG, while the publishing licence in Serbia is owned by a Swiss company Ringier $A G$ which also owns other popular daily newspapers and magazines in this country. In Croatia, this newspaper is bought and costs 5 kunas, while the Serbian version can be found for free at busy locations in Belgrade. Both countries have both printed and online editions. It should be noted that these are popular and frequently visited websites in both countries ${ }^{11}$.

Although they do not have the same editorial staff, their formulations are similar regarding topics and processing. However, there are certain differences in the visual presentation. The choice of menu items on both websites is located at the top of the page, whereby the Serbian version offers a much larger number of sections (Belgrade, EU news, World, Politics, Economy, Society, Culture and arts, Sports, Entertainment, Music, Health, Lifestyle, Travel, IT/Hi-Tech) versus (Home, News, Show, Sport, Life\&Style, Sci/Tech, Viral, Video). The labels of the sections, as well as the article titles, have larger font sizes on the Croatian website, thus they are more visible.

There are also differences in the way the most important articles selected by editors are featured. In the Serbian edition, below the line which lists sections, there is a rectangle which offers the selection of the most important articles. Moving the cursor to the left or to the right offers the review of all the most important articles at that particular moment. By scrolling vertically, new articles appear, each in a separate rectangle (banner), of unequal size. When the bottom of the page is reached, a new set of articles automatically opens.

In the Croatian edition, there is one main article which occupies the central position below the sections. Below this, there is a list of banners which can be smaller or bigger,

\footnotetext{
${ }^{9} \mathrm{http} / / / \mathrm{www} .24 \mathrm{sata} \cdot \mathrm{hr} /$

${ }^{10} \mathrm{http}: / / \mathrm{www} .24$ online.info/

${ }^{11}$ The data taken from http://www.yumreza.info/top_lista.html
} 
depending on their importance. When the bottom of the page is reached, articles are not displayed automatically, and the reader has to click on the link "Load more", in order to open a new set of articles. However, what is common for both editions is the banner principle. Above the titles there is a prominent image, followed by a title, and if the banner has larger dimensions, there are a few first words from the lead of that article below the title. The Serbian version names the author of the image below it, while in the Croatian version, within the image, there is a comment given by the article's author or by the editorial staff which is usually in the form of one to three words ("We have a solution", "Decisive votes", etc.).

At the bottom of the page of the Serbian edition, there are textual links to the menu items, as well as the links to social networks on which this medium has a profile. The bottom of the page of the Croatian edition has a smaller format, and it contains, besides the links to social networks, the following textual links: Mobilni 24sata, Impressum, Pretplata, 24sata.biz, Uvjeti korištenja, Oglašavanje, RSS, Karijera u 24sata.

The very structure of the text in the Serbian edition is such that the title is written in capital letters, below which there is a large-format image. The most important part of the article is typed in bold, and that is always the first paragraph. It uses the inverted-pyramid principle which implies that facts are ordered by importance from top to bottom of the article. The statements are written in italics.

When it comes to the Croatian edition, below the title there is an excerpt from the article which does not necessarily have to be the lead, but it can also be a part of the statement of the article's subject. Images are optional. If there are any, the main image is located below the excerpt of the article, whereby it has been established that several articles contain more images and some articles do not contain any. The characteristic part of the Croatian edition is that certain words or syntagms in the statements are written in bold.

\subsection{Quantitative analysis}

Table 1 The number of articles of the Croatian site "24sata.hr" about Serbia and the Serbian portal "24online.info" about Croatia, in the period from April 1 to 30, 2017

\begin{tabular}{lc}
\hline Online news portals & Number of articles \\
\hline 24 sata.hr & 31 \\
24 online.info & 18 \\
\hline
\end{tabular}

In the period from April 1 to 30, 2017, on the basis of the key words Srbija and Hrvatska, the sites " 24 sata.hr" and "24.online.info" were analysed. It has been determined that the Croatian portal has dedicated more articles (31) to the events and topics related to Serbia than the Serbian portal, which, in the given period, published 18 articles related to Croatia. 
Table 2 The number of articles of the Croatian site "24sata.hr" about Serbia organized by sections, in the period from April 1 to 30, 2017

\begin{tabular}{lc}
\hline Sections & Number of articles \\
\hline News & 27 \\
Sport & 3 \\
Lifestyle & 1 \\
\hline
\end{tabular}

It has been concluded that on the site "24sata.hr", the articles about Serbia were published in three sections: News, Sport and Lifestyle. The 'News' section contained the most articles, 27 of them, while three were dedicated to the topic of sports, and one article was seen in the Lifestyle section. The analysis has shown that the Croatian portal focuses its attention on the daily-informative political and social topics which are related to Serbia, while very little space has been given to articles which can be labelled as soft news.

Table 3 The number of articles from the Serbian site "24online.info" about Croatia, organized by sections in the period from April 1 to 30, 2017

\begin{tabular}{lc}
\hline Sections & Number of articles \\
\hline World & 7 \\
Society & 5 \\
Politics & 3 \\
EU news & 1 \\
Culture and arts & 1 \\
Economy & 1 \\
\hline
\end{tabular}

Out of 18 articles about Croatia, on the portal "24online.info", only one was published in the section 'Culture and arts'. The item 'World' contained the most articles (7), while one is placed in the EU news. Also, 9 articles were dedicated to social (5), political (3) and economic (1) topics which are related to Croatia. It can be concluded that the Serbian site in its reporting about Croatia, just like the Croatian site in its reporting about Serbia, pays most of its attention to social and political events

\subsection{The qualitative analysis}

During the Yugoslav Wars of the nineties, religion was a key determiner of the national identities of the belligerents. Because of this, it has remained a very sensitive topic in intercultural communication in the region. One of the controversial elements of the relations between Serbia and Croatia is the possible canonisation of Croatia's Catholic cardinal Aloysius Stepinac, which the Vatican has to decide on. While in Croatia they believe that he should become a saint, Serbia opposes this position due to the alleged discrediting activities during World War II, i.e. because of his support for the Ustaše regime. The media in Serbia frequently refer to this topic, and during the analysed period one text we found dealt with it. The text entitled "Porfirije: The Results of the Stepinac Committee Still Uncertain"12 is dedicated to a statement made by Porfirije, Metropolitan of Zagreb and

\footnotetext{
${ }^{12}$ The text can be found at: http://www.24online.info/porfirije-jos-neizvestan-rezultat-rada-komisije-o-stepincu/ - published on April 15, 2017, analysed on May 4, 2017.
} 
Ljubljana of Serbian Orthodox Church, in which he said that he hoped that the joint Orthodox-Catholic committee would contribute to a rightful decision, because no one at that moment knew what the Pope would decide. It was interesting that Porfirije sounded conciliatory in his statement: "As the Patriarch said, the decision, whatever it would be, would be obligatory for the Catholics, and we would either be satisfied or dissatisfied with it," where he calls the Catholics to accept the decision, regardless of the outcome.

Religious elements are frequently used for political purposes, which is illustrated by the text "Dodik said to Komarica He Does Not Contribute to Peace and Cohabitation," in which the president of the Republic of Srpska Milorad Dodik responds to a statement previously made by Franjo Komarica, the Bishop of Banja Luka, in which he claimed that Catholics in the Republic of Srpska were endangered ${ }^{13}$. Several times throughout the text, Dodik emphasizes that it is bad to make such accusations on a great Christian holiday: "Unfortunately, you do not respect one or the other Easter, which we could see on this great day. We cannot come over such statements, and that is why I point at your mistakes, which do not contribute to peace and cohabitation in the region, and God can forgive you if he wants to." Although in his letter Dodik insists on religious and overall tolerance, he emphasizes some past events, which still generate various conflicts: "Even when you cry about the dwindling number of Catholics in the Republic of Srpska, you are confined within yourself, you are rejecting the truth, and you do not even think about the fact that most of the Croats from the Republic of Srpska inhabited one of 50,000 cosy flats and houses belonging to the Serbs thrown out of Zagreb, Dubrovnik, Karlovac and other Croatian towns."

The text "Exhibition Jasenovac - the Right Not to Forget Opened"14 shows that the historical conflicts between Serbia and Croatia permeate the media nowadays. In the text, Maja Gojković, the current President of the National Assembly of Serbia, reminds the readers of the Serbian, Jewish and Romani victims of the Jasenovac concentration camp, but at the same time reactivates the historical events so as to use them in passing political messages coming from the current ideological circles in Serbia, which can be seen in the following example: "In the name of the current and the previous generations, Serbia is ready to soothe the troubling memory of the great sacrifice, and will not do that by means of revenge or hatred, but by means of freedom and progress, which will ensure peace, stability, democracy and development. Serbia will demand justice for the victims. In the name of the future generations, today we build a better society, and better Serbia, and a better region." Moreover, the absence of tolerance can be seen in this text as well: "She said that Serbia was obliged to identify and talk about extremism "which had recently been awakened in the neighbouring countries.' As she claimed, we had to notice with regret that on one hand there had been attempts to relativize the crimes that the Independent State of Croatia committed during World War II, while on the other hand we could see a revival of the Ustaše ideology embodied in unveiling a plaque with an Ustaše salute in Jasenovac or attempting to canonise Aloysius Stepinac". Statements like this do not contribute to reconciliation, which both sides are, at least officially, dedicated to. In the text, we can sense a polarization strategy which differentiates Us from Them, i.e. the

\footnotetext{
${ }^{13}$ The text can be found at: http://www.24online.info/dodik-porucio-komarici-da-ne-doprinosi-miru-i-suzivotu/ - published on April 18 2017, analysed on May 42017.

14 The text can be found at: http://www.24online.info/otvorena-izlozba-jasenovac-pravo-na-nezaborav/ published on April 29 2017, analysed on May 42017.
} 
good from the evil or the victim from the one who committed the crime. The frequent unjustified naming, or juxtaposing categories like the Ustaše and the Chetniks, are part of the public discourse in Serbia and Croatia and they determine how different groups see each other, and reinforce the bonds within the groups.

What happened in the Jasenovac concentration camp is still a point of dispute in the relations between the two countries. As they believe that putting up a plaque with the salute "Za dom spremni!" (lit. "For the homeland - ready!"), which the Serbian public regards a provocation, in the vicinity of the memorial park is inappropriate, the Serb National Council stated that the Concentration Camp Break will be honoured independently of the official commemoration. This was announced in the text "Pupovac: SCN Commemoration Separated from the State Commemoration" ${ }^{\text {"15 }}$. Texts like these show that provocations and tension generation are still present and that the ideological construction "For the homeland - ready!" has acquired a deeply negative connotation which evokes strong affective reactions in the Serbian people.

Miodrag Linta, the president of the Association of Serbs in the Region had his say in regard to the Jasenovac Concentration Camp Break commemoration day. In the text titled "Linta: Serbia Obliged to Pass a Resolution on the ISC Genocide" ${ }^{16}$ he demands from the Republic of Croatia to admit the crimes that the Independent State of Croatia committed against Serbs, Jews and Roma, to appropriately mark the places where they were killed, to properly bury their remains and to pay reparations to their families. Among other things, in the text, he says: "The resolution shall demand that all the content glorifying the Independent State of Croatia and Ustaše criminals be erased from the course books, that all monuments dedicated the killed Ustaše or members of the Croatian army marked with 'For the homeland - ready!' be removed, and all the associations and portals elevating the ISC and Ustaše criminals be banned". This text once again shows how historical events which already represent a burden on the complex relations can be accentuated.

Another text in the analysed period is dedicated to Miodrag Linta - the text is titled "Linta: 'For the homeland - ready!' in Split - another proof of Ustashism" ${ }^{17}$. Here Linta again emphasizes that one can still see the signs of the Ustaše ideology in Croatia. He claims that "Exclaiming the Ustaše salute 'For the homeland - ready!' by the former members of the Croatian Armed Forces (CAF-HOS) in Split is another among the many proofs that Ustašism became a legal and widely accepted phenomenon in Croatia".

If we compare the interface design of both portals (Manovič, 2015), it is interesting that on the Serbian version of the 24 sata portal there is no option to comment on a text, there is only an option to express whether one likes or supports the author's view by clicking on a button. Furthermore, there is an option to sort the texts in regard to the number of likes and popularity, but there is no way to determine the total number of likes per text, nor to determine how many times a text has been viewed. There is a way to manipulate these parameters even in those cases in which they are more transparent, whereas the

\footnotetext{
${ }^{15}$ The text can be found at: http://www.24online.info/pupovac-komemoracija-snv-odvojeno-od-drzavne/ published on April 17 2017, analysed on May 42017.

${ }_{16}$ The text can be found at: http://www.24online.info/linta-srbija-ima-obavezu-da-donese-rezoluciju-ogenocidu-ndh/ - published on April 10 2017, analysed on May 42017.

${ }_{17}$ The text can be found at: http://www.24online.info/linta-za-dom-spremni-u-splitu-novi-dokaz-ustastva/ published on 11 April 2017, analysed on 4 May 2017.
} 
chances to deliberately shift a user's attention within the media space of the portal in this case are far greater.

The Serbian Prime Minister Aleksandar Vučić also tackled the issue of Ustašism in the text "Vučić and Dodik claim: Croatia Revives Ustaše Ideology"18 published in the Croatian version of 24 sata. The text was written in a frustrating tone which expresses the animosity of the author towards one of the subjects of this report. "The Serbian Prime Minister and the newly-elected President of this country, Aleksandar Vučić, appeared at the commemoration after being nearly two hours late, thus disrupting the entire programme which had to be temporarily stopped so that Vučić could be applauded in the middle of the memory of the victims of atrocities". The article further pointed out that: "In a long speech, Vučić accused Croatia of trying to revive Ustaše ideology and thus threatened that Serbia would oppose with determination to "the attempts to repeat what happened in the past". Although it has not been explicitly stated that the prevention of new conflicts also implies a new war, the words spoken by Vučić have been reported as a threat, which indicates the passionate reaction of the article's author, but does not release $\mathrm{him} / \mathrm{her}$ from the responsibility of shaping the public opinion in Croatia. The inciting, sensational titles have the purpose of drawing the attention of as wide an audience as possible in order to provide the media company, in this case - a web portal, with a large number of advertisers and a better position on the media market. Besides the fact that using a certain choice of words in titles and title banners has a direct influence on the impression which is created about a person or a group which that title mentions, this kind of language can deepen the existing and incite new conflicts which find their space in the comments section. This article has provoked the largest number of comments, as many as 186. When compared to other articles, which are analysed in the section for the qualitative analysis, the remaining articles have received some 40 or so comments each. Alluding to the events in Sobranje in FYR Macedonia, Vučić pointed out the necessity of respecting the integrity of all states in the region. In an article titled "I have invited Grabar Kitarović and Plenković to the restoration of dialogue" ${ }^{19}$, the Prime Minister of Serbia emphasised that "the Balkans can be stabilized, "with good relations with the Bosnians and the establishment of a serious axis of respect", and that kind of stability, according to him, 'brings a complete peace for the citizens'. The two previously analysed articles show the difference in presenting the relations between Serbia and Croatia. While the former shows a noticeable tendency to ignite conflicts, the latter emphasises the focus on the culture of peace and dialogue. Although politicians declaratively propagate peace, their rhetoric in the public discourse shows the exact opposite. For this reason, public personalities, and politicians in particular, should know that the influence of their words is proportionate to the media space they receive: the leaders of the political stage should have a special responsibility for every spoken word because their rhetoric shapes the awareness of the social community.

An article titled "Vučić: 'I was at Maksimir in 1990 and hatred could be felt!",20 contributes to the fact that the public is even today reminded of the so-called rivalry

\footnotetext{
18 The text can be found at: http://www.24sata.hr/news/vucic-i-dodik-tvrde-hrvatska-ozivljava-ustaskuideologiju-521446_- published on 23 April 2017, analysed on 4 May 2017.

19 The text can be found at: http://www.24sata.hr/news/pozvao-sam-grabar-kitarovic-i-plenkovica-na-obnovudijaloga-522293 - published on 28 April 2017, analysed on 4 May 2017.

${ }^{20}$ The text can be found at: http://www.24sata.hr/sport/vucic-bio-1990-na-maksimiru-na-stadionu-se-osjecala-
} 
which exists between Serbia and Croatia. The article describes the atmosphere before and during the football match between the clubs Red Star and Dinamo in Zagreb in 1990, from the viewpoint of Aleksandar Vučić. This match has remained for by numerous fights among the fans. The disturbing part of the statement is when he states: "Both they and we felt powerful at the time. In our country, the Serbian nationalism was on the rise; we arrived in Zagreb in large numbers. There will never be an away-match which will be visited by so many fans of Red Star. Fans arrived from Glina, Petrinja, Knin, entire Krajina, and even the Dalmatian hinterland. However, at the time, the Croatian nationalism was also on the rise, so Dinamo's fans also felt free and powerful. A genuine hatred was felt at the stadium, and on both sides, you could hear songs with the most horrific lyrics". A healthy competitive spirit implies mutual respect among the players of opposite teams even though each group fights for a better place in the standings. The question which arises is what the aim of evoking such events from the past encouraged by strengthening nationalism on both sides is. Merging nationalism with sports and other social fields implies the implementation of ideology into every pore of society which is, in fact, controlled by such mechanisms. Images which accompany the article also indicate the author's subjectivity (Vujović\&Stojanović Prelević 2014), because the representation of the Prime Minister as a fan awakens the animosity of the Croatian public (Figure 1).
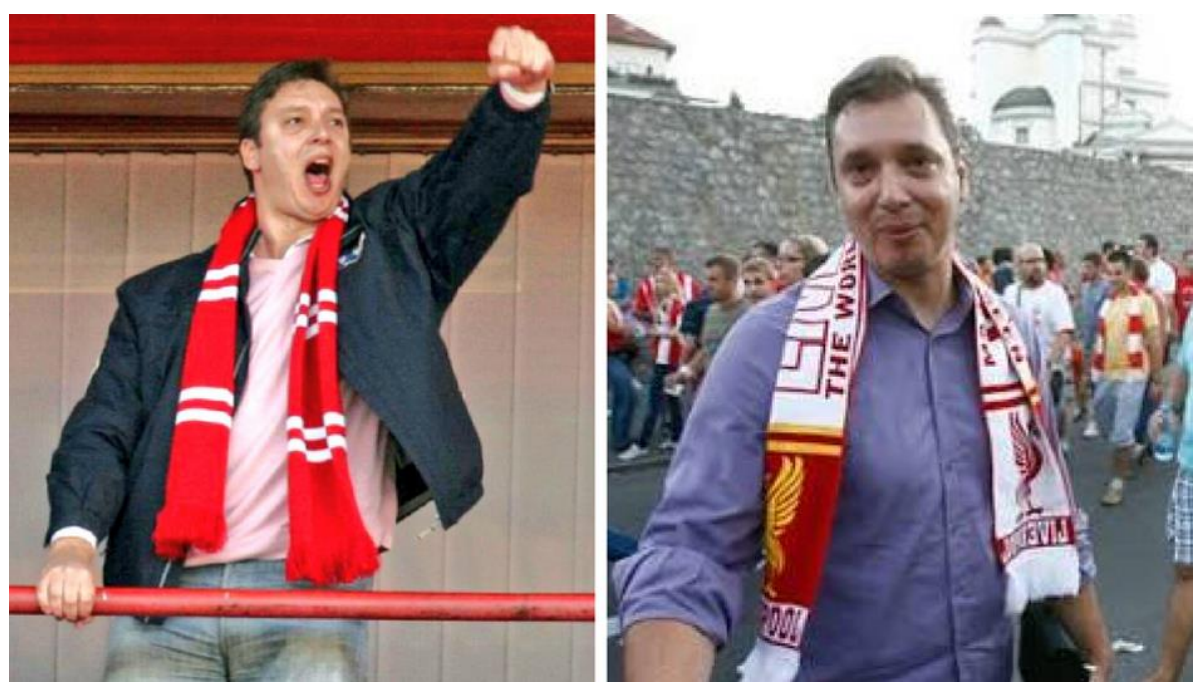

Figure 1 Photo: Twitter

Considering the fact that the quantitative analysis has shown that there are more articles in Croatia about Serbia than vice versa, there are also more topics which are covered. Therefore, in the Croatian edition there are articles about Serbia which can be included in the 'crime section', but which are not in any way connected to the Republic of Croatia. One of the examples is the article: "Horror in Vojvodina: Doctors found a 
dead baby in the toilet"21, which tells that it is not known whether the baby was drowned or stillborn, but particular attention was given to the psychological condition of the mother. The choice of such articles, with an extremely negative connotation, contributes to the creation of a bad image about one people, that is, it can be said that this kind of media selection speaks about the psychological condition of an entire community by giving generalized representations about its members. Although this article has not provoked a large number of users' comments, in relation to all other articles, it has been viewed the most, 8,456 times. This piece of information again confirms the thesis that shocking, spectacular and terrifying stories always find their audience and that, in fact, they attract the attention of the largest part of the audience, which, obviously, craves sensationalism, whatever its nature.

\section{CONCLUDING REMARKS}

The question of creating a national identity has been causing conflict for decades among the countries in the Balkans. A necessary constitutive determinant of each identity, and nation as well, is the emphasis of differences in relation to the Other. In a conflict, we are always the victims, while they are the enemies who are demonised and represented as the main culprits.

In the construction of the representation of other peoples, a large role is played by the media, which promote the acceptable image, while transmitting desirable values and attitudes. Considering the fact that an individual, quite often, uncritically relies on the media in order to find out about the world which surrounds him/her, he/she is susceptible to manipulation. In the previous decades, during the conflicts among Balkan countries, as well as during the process of the creation of national identities, the traditional media have been an important instrument of propaganda. Today, they are joined by the new media, which have become a dominant means of mass communication in the modern age. The media have managed to adjust themselves to the demands of the modern individual and they have become an everyday part of a large number of people in the world. There is almost no traditional medium today which is not present on social networks or similar digital platforms. Besides that, a large number of the media are present only in an online environment. Due to this fact, people receive information even though they do not search for it explicitly. For example, by merely opening their Facebook profile on a computer or a mobile phone, users become exposed to the media contents which are placed among the posts of other users of this social network. This shows that the power of the media is great nowadays as well and that new ways of reaching the audience are constantly being discovered. Techniques and communication tools, as well as the strategies of representing the Other are being improved. Pointing out one's own superiority and other's inferiority, and emphasising the differences and not the bonds which connect the two peoples can be seen in the media every day. Very often, stereotypes are those which dictate the way in which we will view the members of other countries and what kind of prejudices we will create. A stereotypical image which has been created for decades is difficult to modify overnight.

\footnotetext{
${ }^{21}$ The text can be found at: http://www.24sata.hr/news/kod-kuce-rodila-bebu-lijecnici-je-pronasli-mrtvu-u-wcskoljki-521896 - published on 26 April 2017, analysed on 4 May 2017.
} 
The paper has shown that Serbia and Croatia are most often mentioned on the analysed portals in the context of daily, political and social events. In case of linguistic closeness of two social communities, the identifier on the basis of which they will differ starts to be religion. This is particularly present on the territories of ex-Yugoslavian countries. Citing the historical events which represent the point of contention can be found in several articles which refer to the anniversary of the breakthrough from the Jasenovac concentration camp. The commemoration of that event is permeated by a clear ideological messages of the ruling elite in Serbia, which, as it seems, uses every opportunity to revive the conflicts from the past. The leading personalities from Serbia, such as the Prime Minister and newly-elected President Aleksandar Vučić and the President of the National Assembly Maja Gojković speak about the revival of the Ustaše ideology, as it is shown by the analysis of the media articles. Instead of searching for elements which would bring the two nations closer, as well as establishing high-quality cooperation in all social fields, the public, media discourse of Serbia and Croatia abounds in stereotypes and polarisations which strengthen and deepen the existing fractures in their relations. When the ideological threads go through all the pores of modern society, no area remains untouched, nor is any interpretation clean from the ideological layers of the ruling circles. The article which mentions the match between Red Star and Dinamo, played in Zagreb in 1990, is a good example of such strategies intensifying sports rivalry by making references to the national identities of teams and fans. The 'poisoned' sporting spirit does not only have the aim of beating the opponent in the game, but of using its victory to humiliate and degrade his/her dignity and to show one's own superiority. Due to such relations, our share in the conflict is being relativized, while the share of the other side is always in the centre of attention and represents an unending source of negative rhetoric. In this way, even young individuals who had not been born during the war and who should, declaratively, build the path of reconciliation, are being drawn into the media-constructed conflicts which are waged in a virtual world as well. This makes it more difficult to establish a dialogue between the two peoples, even when it comes to future generations. The unjustified generalizations, which are a part of the everyday media rhetoric, can hardly be stopped, especially if they are an integral part of the plan of the ruling hegemon. Only the spirit of criticism and interpersonal contacts with other cultures prove to be the real paths for breaking the prejudices and unmasking the mediaconstructed worldview.

\section{REFERENCES}

Đerić, G. "Drugi u poslekonfliktnom stanju". Filozofija i društvo 3 (2008): 259-271. Available at: http://www.doiserbia.nb.rs/img/doi/0353-5738/2008/0353-57380803259D.pdf, accessed on 18 March 2017.

Đorđević, Jelena. Postkultura. Beograd: Clio, 2009.

Galloway, Alexander. The Interface Effect. Cambridge: The Polity Press, 2012. Available at: http://art.yale.edu/file_columns/0000/1404/galloway_alexander_r_-_the_interface_effect.pdf, accessed on 16 March 2017.

Hannu-Pekka, L. "Moć i uloga medija u krizama”. MediAnali: 6, 3 (2009): 9-26. Taken from: http://hrcak.srce.hr/ 44524, accessed on 15 March 2017.

Jevtović, Z. i S. Milašinović. "Društveni konflikti i medijska konstrukcija”. U Polja geopolitike, edited by Lj. Despotović i V. Konatar, 524-549. Novi Sad: Kultura polisa, Fakultet za evropske pravno političke studije, 2016. Available at: http://kpolisa.com/KPP2016/KPP2016_PoljaGeopolitike.pdf, accessed on 15 May 2017.

Kecmanović, Dušan. Ethnic Times: Exploring Ethnonationalism in the Former Yugoslavia. London: Praeger, 2002. 
MacDonald, David Bruce. Balcan holocausts? Serbian and Croatian Victim-centred Propaganda and the War in Yugoslavia. Manchester: Manchester University Press, 2002.

Manovič, Lev. Jezik novih medija, Beograd: Clio, 2015.

Mesić, Milan. Multikulturalizam: društveni i teorijski izazovi, Zagreb: Školska knjiga, 2006.

Miladinović, Slobodan. Etnički odnosi $i$ identiteti. Beograd: Fakultet organizacionih nauka, 2009. Available at: https://www.academia.edu/7683231/Slobodan_Miladinovi\%C4\%87_ETNI\%C4\%8CKI_ODNOSI_I_IDENTITE TI, accessed on 14 March 2017.

Ninković-Slavnić, D. "Medijska reprezentacija grupnih identiteta”. CM 19, 6 (2011): 15-37.

Papacharissi, Z. "The Virtual Sphere: The Internet as a Public Sphere". New Media \& Society 1, 4 (2002): 9-27. Available at: http://zizi.people.uic.edu/Site/Research_files/VirtualSphere.pdf, accessed on 15 March 2017.

Puddephatt, Andrew. Voice of War: Conflict and the Role of the Media. Copenhagen: International Media Support, 2006. Available at: https://www.mediasupport.org/wp-content/uploads/2012/11/ims-voices-ofwar-2006.pdf, accessed on 19 March 2017.

Stevanović, Branislav. Političko-kulturne interferencije. Niš: Studentski kultrni centar, 2013.

Stojanović, Đ. i M. Pešić. "Realizam i kontruktivizam u svetskoj politici: problem nacionalnih identiteta". In Polja geopolitike, edited by Lj. Despotović i V. Konatar, 29-55. Novi Sad: Kultura polisa, Fakultet za evropske pravno političke studije, 2016. Available at: http://kpolisa.com/KPP2016/KPP2016_ PoljaGeopolitike.pdf, accessed on 17 May 2017.

Stojanović-Prelević, I., I. Stojković i M. Milutinović. "Senzibilnost i senzacionalizam u izveštavanju štampanih medija o narodima u regionu: Analiza sadržaja Blic, Politika i Kurir". U Uloga medija u normalizaciji odnosa na Zapadnom Balkanu, 141-159.Novi Sad: Filozofski fakultet i Centar za istraživanje religije, politike i društva Novi Sad, 2014.

Stojković, Branimir. Identitet i komunikacija. Beograd: Fakultet političkih nauka, 2002.

Tripković, M. „Etnički sukobi u multikulturnim društvima i (ne)mogućnosti njihovog predupređivanja“. Sociološki pregled 2, 39 (2005): 99-121. Available at: http://www.socioloskipregled.org.rs/Tekstovi/ 2(2005)/Tripkovic.PDF, accessed on 19 March 2017.

Vilović, G. "Govor mržnje”. Političke analize 6, 2 (2011): 68-70. Available at: http://hrcak.srce.hr/175715, accessed on 15 March 2017.

Vujović, M. and N. Obradović. "Online Media and Intercultural Communication”. Facta Universitatis Series: Philosophy, Sociology, Psychology and History 16, 1 (2017): 51-61.

Vujović, M. and I. Stojanović Prelević. "Ethics of Newspaper Photography". Facta Universitatis Series: Philosophy, Sociology, Psychology and History 13, 3 (2014): 123-135.

Vulić, T. and D. Pavlović. "Domestic Violence in the Serbian Daily Press: From Facts to Sensationalism". Facta Universitatis Series: Philosophy, Sociology, Psychology and History 13, 3 (2014): 111-122.

Wodak, R. "Critical Discourse Analysis". In Continuum Companion to Discourse Analysis, edited by K. Hyland and B. Paltridge, 39-54. London and New York: Continuum International Publishing Group, 2001.

\section{ONLAJN MEDIJI KAO GENERATORI KONFLIKATA}

Mediji su oduvek imali veliku moć u konstruisanju stavova i mišljenja publike, pa ne čudi što se stalno prilagođavaju savremenim tokovima i načinima na koje publika dolazi do informacija. Zahvaljujući popularnosti i mogućnostima koje internet pruža, mediji su bili prinuđeni da konvergiraju ka onlajn formama izveštavanja. Osim toga, internet je omogućio brisanje državnih granica u pogledu informisanja, pa publika lakše može doći do saznanja o događajima iz bilo kojeg dela sveta. Masmedijska komunikacija tako dobija nove obrise, usmeravajući društvene tokove na globalnom nivou. Iako ovakav trend može biti koristan, on sa sobom može nositi i određene opasnosti. Tako novi mediji mogu postati platforma za međunarodne konflikte i dovesti do potencijalnog prekida dobrih odnosa među državama. S obzirom na to da odnose između Srbije i Hrvatske karakteriše ne tako davna ratna prošlost, u ovom radu istraživali smo na koji način srpski i hrvatski onlajn mediji izveštavaju o odnosu dve države iz ugla političkih odnosa, medijske prezentacije onog drugog, kao i koliku ulogu savremeni mediji imaju u provociranju novih konflikata. Kvantitativno-kvalitativnom analizom sadržaja analizirana je srpska i hrvatska verzija portala ,24 sata" u periodu od 1. do 30. aprila 2017. godine.

Ključne reči: internet, konflikti, Srbija, Hrvatska, novi mediji, izveštavanje. 